\title{
Nanotechnology in Dentistry
}

\author{
Nanotecnologia na Odontologia \\ Nanotecnología en Odontología \\ José Alcides Almeida de ARRUDA ${ }^{1}$ \\ Cinthia Figueiredo de OLIVEIRA ${ }^{1}$ \\ Carina Silva de PAULA ${ }^{2}$ \\ Vanessa Carla Furtado MOSQUEIRA ${ }^{2}$ \\ Amália MORENO ${ }^{1}$ \\ Ricardo Alves MESQUITA ${ }^{\mathbf{1}}$ \\ ${ }^{1}$ Departamento de Clínica, Patologia e Cirurgias Odontológicas da \\ Faculdade de Odontologia da Universidade Federal de Minas Gerais (FO-UFMG), 31.270-010 Belo Horizonte, MG, Brasil \\ ${ }^{2}$ CIFarmácia, Departamento de Farmácia, Faculdade de Farmácia, UFOP, Universidade Federal de Ouro Preto, \\ 35400-000 Ouro Preto, MG, Brasil
}

\begin{abstract}
Introduction: Nanotechnology is a rapidly expanding field that encompasses the development, manipulation, and application of structures on the nanometer scale. Applications of nanotechnology to dentistry are particularly promising and comprise materials and devices designed to achieve maximal therapeutic efficacy with minimal side effects. Objective: This review discusses the advantages of nanotechnology and the different types of nanostructures used in dentistry. Material and Method: In this study, online databases: pubmed, medline and scielo were searched to analyse the current understanding of the potential of nanotechnology in dentistry, including the restoration of tooth structure with nanocomposites and the development of nanoparticles for dentin remineralisation, drug delivery, disease diagnostics, oral analgesia, oral hygiene maintenance, local anaesthesia, tooth desensitisation, and bone tissue repair. Results: The study demonstrated a wide range of nanotechnological strategies in different dentistry areas and suggests that nanotechnology-based delivery systems may be very useful to improve treatment, prevention and repair in dentistry in the future. Conclusion: There is little or no clinical experience for the nanotechnology-based drug delivery systems cited herein. Safety assessments and clinical trials are the next step in their development.

Descriptors: Nanotechnology; Dental Research; Biocompatible Materials.
\end{abstract}

\section{Resumo}

Introdução: A nanotecnologia é um campo em rápida expansão que engloba o desenvolvimento, manipulação e aplicação de estruturas na escala nanométrica. Aplicações da nanotecnologia para odontologia são particularmente promissoras e compreendem materiais e dispositivos projetados para atingir a máxima eficácia terapêutica com efeitos colaterais mínimos. Objetivo: Esta revisão discute as vantagens da nanotecnologia e os diferentes tipos de nanoestruturas na odontologia. Material e método: Neste estudo, bases de dados online: pubmed, medline e scielo foram utilizadas para analisar a atual compreensão do potencial da nanotecnologia na odontologia, incluindo restauração da estrutura do dente com nanocompósitos e desenvolvimento de nanopartículas para remineralização da dentina, aplicação de drogas, diagnóstico de doença, analgesia oral, manutenção de higiene bucal, anestesia local, dessensibilizante dental e reparo do tecido ósseo. Resultados: O estudo demonstrou uma ampla gama de estratégias nanotecnológicas nas diferentes áreas da odontologia e sugere que os sistemas de vias baseadas em nanotecnologia podem ser muito úteis para melhorar o tratamento, prevenção e reparação na odontologia no futuro. Conclusão: Há pouca ou nenhuma experiência clínica para os sistemas de entradas de drogas baseada em nanotecnologia citados neste trabalho. Avaliações de segurança e ensaios clínicos são o próximo passo no seu desenvolvimento.

Descritores: Nanotecnologia; Pesquisa em Odontologia; Materiais Biocompatíveis.

\section{Resumen}

Introducción: La nanotecnología, es un campo que está en rápida expansión que engloba el desarrollo, manipulación y aplicación de estructuras en escala nanométrica. Las aplicaciones de la nanotecnología en Odontología son interesantes y comprenden materiales y dispositivos proyectados para brindar la máxima eficacia terapéutica con mínimos efectos colaterales. Objetivo: Esta revisión discute las ventajas de la nanotecnología y los diferentes tipos de nanoestructuras en Odontología. Material y método: En este estudio fueron buscados artículos en las bases de datos Pubmed, Medline y Scielo para analizar la aplicación de la nanotecnología en Odontología, incluyendo materiales como composites para restauración de dientes y el desarrollo de nano partículas para remineralización de dentina, aplicación de fármacos, diagnóstico de enfermedades, analgesia oral, mantenimiento de la higiene bucal, anestesia local, desensibilizador dental y reparo do tejido óseo. Resultados: Fue encontrada una amplia gama de estrategias nanotecnológicas en Odontología áreas y sugiere que los sistemas y vías basadas en nanotecnología pueden ser muy útiles para mejorar el tratamiento, prevención y reparación en Odontología futuramente. Conclusión: Hay poca o ninguna experiencia clínica para los sistemas de fármacos basada en nanotecnología en este trabajo. Evaluaciones seguras y ensayos clínicos son el próximo paso en su desarrollo.

Descriptores: Nanotecnología, Investigación Dental; Materiales Biocompatibles.

\section{INTRODUCTION}

Nanotechnology can be defined as the science involved in the design, synthesis, characterisation, and application of materials and devices whose smallest functional organization in at least one dimension is on the nanometer scale ${ }^{1,2}$. It is an emerging field that has contributed to the development of novel diagnostic and therapeutic agents, with the advantage of enhancing drug accumulation at the site of interest and avoiding side effects common to small molecule drugs ${ }^{3}$. The small size, improved chemical stability and apparent solubility of the encapsulated molecules, as well as the multifunctionality of nanoparticles, are features that open up new perspectives for biological research ${ }^{4}$. Sustained drug release systems have many advantages, such as reducing side effects and dosage frequency, optimizing therapy by greater interaction with the biological targets, and improving patient acceptance ${ }^{5}$. Novel drug delivery systems would also protect drugs from degradation and improve the pharmacokinetics of easily degradable peptides and proteins. Furthermore, these systems could enhance permeation through tissues and absorption of the bioactive molecule. The advantage of nanoparticles over microparticles is their ability to travel through the bloodstream without sedimentation and their small size that permits them to penetrate tissues such as tumours ${ }^{6}$. The disadvantages of the use of nanotechnology in dentistry are the high costs of the products and insufficient knowledge about the toxicity of such formulations. 
Nanoparticles have different morphologies and can be of organic, inorganic or mixed origin. Ceramic nanoparticles are typically composed of inorganic compounds such as alumina or silica. However, the nanoparticle core is not limited to these two materials and metals, metal oxides, and metal sulfides can be used to produce nanostructures of variable size, shape, and porosity ${ }^{7}$. Matrix-type nanocarriers, such as nanoclays or mesoporous silica nanoparticles, are non-hollow nanoparticles. Nanospheres are polymeric matricial nanoparticle systems that slowly deliver their load either through diffusion from the matrix or matrix erosion (Fig. 1A). Reservoir-type nanocarriers, also referred to as nanocapsules, are a carrier of choice for the incorporation of highly lipophilic drugs because they can dissolve or disperse drugs with high payload ${ }^{8}$ in their inner core (Fig. 1B). In nanocapsules, the oily nanodroplets are surrounded by a polymeric biodegradable wall that can be chemically modified to prolong blood circulation time or to improve the targeting properties of the carrier'. Most polymeric nanoparticles are biodegradable and biocompatible and have been adopted as the preferred method for nanomaterial-based drug delivery in chemotherapy. Nanoparticle formulations include those made from gelatins, chitosan, poly(lactic-co-glycolic acid) copolymer, polylactic acid, polyglycolic acid, poly(alkylcyanoacrylate), poly(methylmethacrylate), and poly(butyl) cyanoacrylate. There is also a variety of nanoparticles made from fatty substances including both matrix-type nanocarriers, such as solid lipid nanoparticle and nanostructured lipid carriers, and reservoir-type nanocarriers, such as liposomes. The structure of lipid nanoparticles resembles that of nanoemulsions (Fig. 1C). Solid lipid nanoparticles are lipidbased submicron colloidal carriers. In general, they are more stable than liposomes in biological systems due to their relatively rigid core consisting of hydrophobic lipids that are solid at room and body temperatures, surrounded by a monolayer of phospholipids (Fig. 1D). These aggregates are further stabilized by the inclusion of high concentrations of surfactants ${ }^{10}$. Liposomes are more complex structures consisting of two or more centric lipid bilayers between internal and external aqueous compartments. They are formed by apolar and polar components, usually combined with phospholipids (Fig. 1E) $)^{11,12}$.

Nanocrystals are aggregates of molecules that can be combined into a crystalline form of the drug surrounded by a thin coating of surfactant. A nanocrystalline species can be prepared from a hydrophobic compound and coated with a thin hydrophilic layer (Fig. 1F). Recently, semiconductor nanocrystals, also called quantum dots, have emerged as a powerful class of fluorescent probes ${ }^{13}$. Quantum dots are highly photo-stable with broad absorption spectra and narrow size-tunable emission spectra. Recent advances in the synthesis of these materials have resulted in bright, sensitive, extremely photo-stable, and biocompatible semiconductor fluorophores ${ }^{13}$.

Figure 1 shows another nanostructure, called dendrimers. These molecules are polymer-based macromolecules formed from monomeric or oligomeric units, so that each layer of branching units doubles or triples the number of peripheral groups. Dendrimers generally have a symmetrical structure (fractal type), with the potential to create an isolated 'active site' core area through chemical functionalization (Fig. 1G). Modification of the degree of branching allows for encapsulation of a molecule within this structure $^{14}$. Another type of drug delivery system are nanotubes. Nanotubes can be organic or inorganic and can be produced as single- or multiwalled structures. They are self-assembling sheets of atoms arranged in tubes (Fig. 1H). A popular version of a nanotube involves the use of soluble fullerene derivatives, such as $\mathrm{C}_{60}{ }^{15}$. Although they are considered promising for pharmaceutical applications, it has recently been demonstrated that nanotubes are acutely toxic and may cause cell death via an oxidative stress pathway ${ }^{16}$.

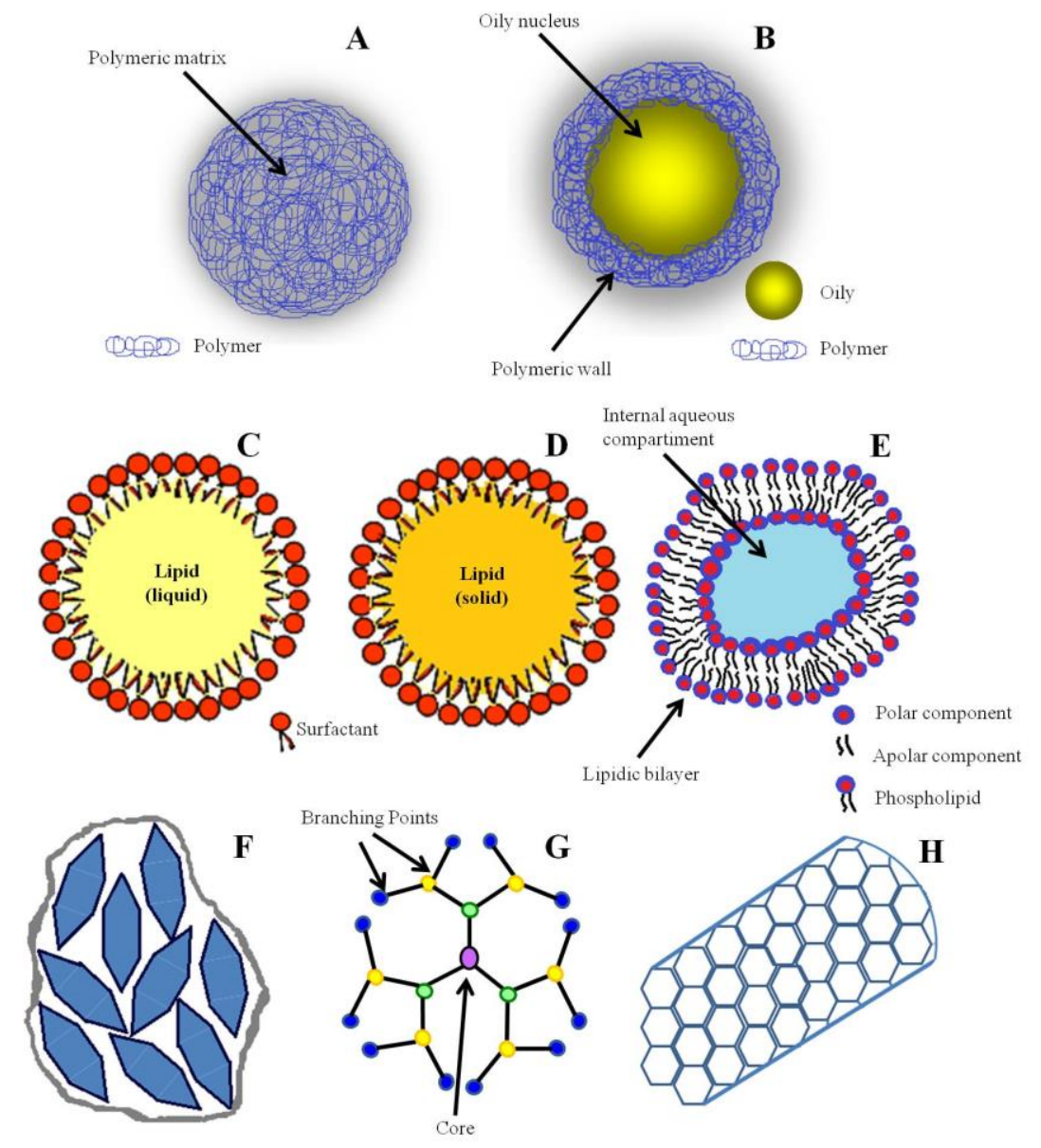

Figura 1: Examples of nanocarriers as delivery vehicles. (A) Polymeric nanosphere, (B) polymeric nanocapsule, (C) nanoemulsion, (D) solid lipid nanoparticle, (E) liposome, (F) nanocrystal, (G) dendrimer, and $(\mathrm{H})$ nanotube.

\section{MATERIALS AND METHODS}

In this review, the Medline database comprising the period from 2000 to March 2017 was searched using the following keywords: drug delivery; nanotechnology; nanomedicine; nanodentistry; and nanoparticles. The primary outcome of interest was the current understanding of the potential of nanotechnology in dentistry, including the restoration of tooth structure with nanocomposites and the development of nanoparticles for dentin remineralisation, drug delivery, disease diagnostics, oral analgesia, oral hygiene maintenance, local anaesthesia, tooth desensitisation, and bone tissue repair.

\section{NANOTECHNOLOGY AND DENTAL APPLICATIONS}

There are nowadays many examples of dental composites using nanomaterials, thus demonstrating the practical importance of nanotechnology $y^{17,18}$. There are nanofill composites that contain nanomer particles or nanohybrids that contain finely ground glass filler and prepolymerized nanofiller ${ }^{19}$. The types of nanofill composites used are silica, tantalum ethoxide, zirconiasilica, alumina, nanofibrillar silicate, ordered colloidal particles, and titanium oxide ${ }^{19}$. The addition of F, Ca or $\mathrm{PO}_{4}$ nanoparticles may alter or improve the properties of nanocomposites. $\mathrm{Xu}$ et $\mathrm{al}^{20}$ observed that composites containing $\mathrm{CaF}_{2}$ nanoparticles had a 3-fold higher flexural strength than resin-modified glass ionomer. Other examples are nanocomposites containing nanoparticles of amorphous 
calcium phosphate, which had a 2-fold higher strength than an ordinary composite, reducing potential secondary caries and restoration fracture ${ }^{21}$, and silver-containing materials that improve the polymerisation process ${ }^{22}$. Taha et al. ${ }^{23}$ found that nanoceramic composites are very resistant, showing higher cuspal fracture resistance than microhybrid or ormocer restorations. It can be used as pit and fissure sealants, allowing deeper penetration ${ }^{24}$. Comparing the fluoride release from a conventional glass ionomer cement and from a fluoride nanoparticle, Neelakantan et al. ${ }^{25}$ observed a higher release for the conventional ionomer on the first three days, but a maximum release. Since fluoridereleasing dental restoratives are promising to promote remineralisation and to combat caries, Weir et al. ${ }^{26}$ developed nanocomposites containing calcium fluoride nanoparticles $\left(\mathrm{nCaF}_{2}\right)$ and investigated their long-term mechanical durability including wear, thermal-cycling and long-term water-aging behavior. Combining $\mathrm{nCaF}_{2}$ with glass particles yielded nanocomposites with long-term mechanical properties and with little fluoride release, indicating that the $\mathrm{nCaF}_{2}$ nanocomposites are promising for load-bearing and caries-inhibiting restorations. The advantages of nanoparticle materials for dental filling are reduced polymerisation shrinkage, enhanced resistance, biocompatibility, high elastic modulus, and improved optical properties of the dental composites ${ }^{27}$. Bonding agents containing nanoparticles (a modified nanoclay containing $\mathrm{Na}^{+}$) that can improve mechanical properties and bond strength are commercialized, but no improvement in dentinal microleakage was observed in short- or long-term studies $^{28}$.

Disadvantages of composite restorations are that they accumulate more biofilm and are subject to faster degradation than those prepared with other materials ${ }^{29,30}$. For these reasons, dental materials with antibacterial properties need to be developed to reduce biofilm formation at the tooth-restoration margins without interfering with the mechanical properties of the adhesive. The most promising agents with antibacterial properties are metallic nanoparticles. Silver nanoparticles have proved to confer antibacterial activity to dental composite resins ${ }^{31}$. Ai et al. ${ }^{32}$ prepared composite resin reinforced with silver nanoparticle-laden hydroxyapatite nanowires. These composite resins were evaluated regarding their mechanical properties, silver ion release, cytotoxicity, and antibacterial activity. The resulting composite resins exhibited high antibacterial activity at low addition amounts of silver nanoparticles, while no significant cytotoxicity was observed. $^{32}$ Copper nanoparticles showed higher antibacterial activity compared to silver nanoparticles against Escherichia coli, Bacillus subtilis and Staphylococcus aureus ${ }^{33,34}$. Gutiérrez et al. ${ }^{35}$ studied the mechanical and microbiological properties and drug release modeling of an etch-and-rinse adhesive containing copper nanoparticles. The addition of copper nanoparticles at concentrations of up to $1 \%$ provided antimicrobial properties and preserved the bonding to dentin after 1 year, without reducing the mechanical properties of the adhesives ${ }^{35}$.

Different dentin remineralisation strategies have been investigated. An alternative strategy that has become the focus of many studies in this field is the use of nanoparticles for the management of dental caries. Nano-sized calcium fluoride ${ }^{36}$, nano-sized carbonated apatite ${ }^{37}$, carbonate hydroxyapatite nanocrystals ${ }^{38}$, hydroxyapatite nanoparticles $^{39-41}$ and nanoparticulate bioactive glass ${ }^{42}$ are nanomaterials that seem to increase the mineral content of enamel and dentin. Besinis et al. ${ }^{41}$ investigated the ability of colloidal silica and hydroxyapatite nanoparticles to infiltrate the collagen structure of demineralized dentin. The authors observed that silica nanoparticles can penetrate dentin and remain embedded within the collagen matrix. The infiltration of demineralised dentin with sol-gel hydroxyapatite nanoparticles was limited but was significantly increased when combined with the deflocculating agent sodium hexametaphosphate and when acetone was used as transport vehicle ${ }^{41}$.

Nanotechnology is also useful in periodontology. Some antibiotics have been encapsulated to improve their delivery and to reduce their toxicity compared to oral administration. Antibacterial nanoparticles exhibit higher antibacterial activity than antibacterial powders because of their greater surface area and charge density, which allows greater interaction with the negatively charged surface of bacterial cells. Kishen et al. ${ }^{43}$ highlighted the potential advantage of cationic nanoparticles in root canal disinfection. Studies using oral mucoadhesive metronidazole benzoate delivery systems have shown good levels of absorption ${ }^{44}$. Botelho et al. ${ }^{45}$ reported a decrease in bone loss and myeloperoxidase activity in a murine model using a doxycycline gel with nanospheres. In periodontal surgery, current clinical trials suggest the use of nanocrystalline hydroxyapatite paste for the treatment of periodontal intrabony defects, reducing probing depth and gingival recession and increasing clinical attachment level, with the results being similar to those obtained with autogenous grafts ${ }^{46,47}$. Nanocomposite films can be used to deliver antimicrobials such as tetracycline and alendronate to periodontal pocket fluids via guided tissue regeneration membranes, reducing alkaline phosphatase activity and bone formation ${ }^{48}$. Some products have been developed to treat dentin hypersensitivity, including dentifrices with nanocrystals that can selectively occlude tubules, offering patients a permanent cure ${ }^{49}$. Another study demonstrated that a desensitiser product based on nanostructured bioactive glass reduces tubular fluid flow and, probably, dentinal hypersensitivity ${ }^{50}$.

Research on mesoporous materials for biomedical purposes has experienced an outstanding increase during recent years. Mesoporous materials are intended for both systemic delivery systems and implantable local delivery devices. The latter application provides very promising possibilities in the field of bone tissue repair because of the excellent behavior of these materials as bioceramics. ${ }^{7}$ Titanium nanopores have many advantages over conventional implants since they are more resistant because of their lower elastic modulus and improved mechanical adhesion to the bone, permitting the deposition of cells inside the nanopores ${ }^{51,52}$.

Nanoparticle technology is also used in local anaesthesia $^{53-56}$. Clinical studies have tested colloidal solutions of nano-sized particles containing lidocaine, bupivacaine and tetracaine ${ }^{53}$. Tetracaine encapsulated in liposomes injected into the tail of rats provided anaesthesia for 43 hours in the absence of neural toxicity ${ }^{54}$. FranzMontan et al. ${ }^{57}$ showed that topical administration of $10 \%$ benzocaine encapsulated in liposomes increases soft tissue anaesthesia but does not induce pulpar anaesthesia. Ribeiro et al. ${ }^{58}$ prepared nanostructured lipid carriers using cetyl palmitate and capric/caprylic triglycerides as structural lipids and Pluronic 68 as the colloidal stabiliser for the delivery of local anaesthetics (lidocaine and prilocaine) used 
in dental practice.

In an in vitro study using oral squamous cell carcinoma cell lines, Holpuch et al. ${ }^{59}$ found that nanoparticle-based drug delivery systems provide higher final intracellular levels than bolus administration, suggesting a possible chemotherapeutic application. Liposomal formulations of nystatin, a commonly used antibiotic, include lipid vesicles made of mixtures of palmitoyloleoylphosphocholine/ergosterol/cholesterol ${ }^{60}$ or a modified form with amphiphilic polymers ${ }^{61}$. Using a conventional liposomal formulation of nystatin, $\mathrm{Ng}$ et al. ${ }^{62}$ observed an about 4-fold decrease in erythrocyte toxicity. De Logu et al. ${ }^{63}$ suggested a lower activity against Candida albicans for the encapsulated form of ketoconazole and miconazole at $25 \mathrm{mg} / \mathrm{L}$ and concluded that the activity of these formulations is not predictable and that encapsulation can affect different drugs differently.

\section{CONCLUSIONS}

There is little or no clinical experience for the nanotechnology-based drug delivery systems cited here. Despite their future potential, more studies are needed to prove their true applicability.

\section{ACKNOWLEDGEMENT}

This work was supported by the Brazilian National Council for Scientific and Technological Development $(\mathrm{CNPq})$. The author, RA Mesquita was the recipient of a research fellowship from $\mathrm{CNPq}$.

\section{REFERENCES}

1. Emerich DF, Thanos CG. Nanotechnology and medicine. Expert Opin Biol Ther. 2003; 3(4):655-63.

2. Sahoo SK, Labhasetwar V. Nanotech approaches to drug delivery and imaging. Drug Discov Today. 2003; 8(24):1112-20.

3. Heath JR, Davis ME. Nanotechnology and cancer. Annu Rev Med. 2008; 59:251-65.

4. Heath JR, Phelps ME, Hood L. NanoSystems biology. Mol Imaging Biol. 2003; 5(5):312-25.

5. Ricci-Júnior E, Marchetti JM. Zinc(II) phthalocyanine loaded PLGA nanoparticles for photodynamic therapy use. Int J Pharm. 2006; 310(1-2):187-95.

6. Chen L, Henein G, Luciani V. Nanofabrication techniques for controlled drug-release devices. Nanomedicine (Lond). 2011; 6(1):1-6.

7. Vallet-Regí M, Balas F, Arcos D. Mesoporous materials for drug delivery. Angew Chem Int Ed Engl. 2007; 46(40):7548-58.

8. Legrand P, Barrat G, Mosqueira VCF, Fessi H, Devissaguet JP. Polymeric nanocapsules as drug delivery systems: A review. STP Pharma Sciences. 1999; 9:411-8.

9. Mosqueira VC, Legrand $\mathrm{P}$, Morgat JL, Vert $\mathrm{M}$, Mysiakine E, Gref R et al. Biodistribution of longcirculating PEG-grafted nanocapsules in mice: effects of PEG chain length and density. Pharm Res. 2001;18(10):1411-9.

10. Müller RH, Mäder K, Gohla S. Solid lipid nanoparticles (SLN) for controlled drug delivery - a review of the state of the art. Eur J Pharm Biopharm. 2000; 50(1):161-77.

11. New RRC. Liposomes: A Practical Approach. 1st ed. Oxford: Oxford University Press; 1990.

12. Nguyen S, Hiorth M, Rykke M, Smistad G. The potential of liposomes as dental drug delivery systems.
Eur J Pharm Biopharm. 2011;77(1):75-83.

13. Bruchez M Jr, Moronne M, Gin P, Weiss S, Alivisatos AP. Semiconductor nanocrystals as fluorescent biological labels. Science. 1998; 281(5385):2013-6.

14. Quintana A, Raczka E, Piehler L, Lee I, Myc A, Majoros I et al. Design and function of a dendrimerbased therapeutic nanodevice targeted to tumor cells through the folate receptor. Pharm Res. 2002; 19(9):1310-6

15. Porter AE, Gass M, Muller K, Skepper JN, Midgley PA, Welland M. Direct imaging of single-walled carbon nanotubes in cells. Nat Nanotechnol. 2007;2(11):713-7.

16. Manna SK, Sarkar S, Barr J, Wise K, Barrera EV, Jejelowo $\mathrm{O}$ et al. Single-walled carbon nanotube induces oxidative stress and activates nuclear transcription factor-kappaB in human keratinocytes. Nano Lett. 2005; 5(9):1676-84.

17. Ure D, Harris J. Nanotechnology in dentistry: reduction to practice. Dent Update. 2003; 30(1):10-5.

18. Elkassas D, Arafa A. The innovative applications of therapeutic nanostructures in dentistry. Nanomedicine 2017; 13(4):1543-62.

19. Senawongse P, Pongprueksa P. Surface roughness of nanofill and nanohybrid resin composites after polishing and brushing. J Esthet Restor Dent. 2007;19(5):265-73.

20. Xu HH, Weir MD, Sun L, Moreau JL, Takagi S, Chow $\mathrm{LC}$ et al. Strong nanocomposites with $\mathrm{Ca}, \mathrm{PO}(4)$, and $\mathrm{F}$ release for caries inhibition. J Dent Res. 2010; 89(1):19-28.

21. Moreau JL, Sun L, Chow LC, Xu HH. Mechanical and acid neutralizing properties and bacteria inhibitionn of amorphous calcium phosphate dental nanocomposite. J Biomed Mater Res B Appl Biomater. 2011;98(1):80-8.

22. Durner J, Stojanovic M, Urcan E, Hickel R, Reichl FX. Influence of silver nano-particles on monomer elution from light-cured composites. Dental Mater. 2011; 27(7):631-6.

23. Taha DG, Abdel-Samad AA, Mahmoud SH. Fracture resistance of maxillary premolars with class II MOD cavities restored with Ormocer, Nanofilled, and Nanoceramic composite restorative systems. Quintessence Int. 2011; 42(7):579-87.

24. Singh S, Pandey RK. An evolution of nanocomposites as pit and fissure sealants in child patients. J Ind Soc Pedod Prev Dent. 2011; 29(4):294-9.

25. Neelakantan P, John S, Anand S, Sureshbabu N, Subbarao C. Fluoride release from a new glass-ionomer cement. Oper Dent. 2011; 36(1):80-5.

26. Weir MD, Moreau JL, Levine ED, Strassler HE, Chow $\mathrm{LC}, \mathrm{Xu} \mathrm{HH}$. Nanocomposite containing $\mathrm{CaF}(2)$ nanoparticles: thermal cycling, wear and long-term water-aging. Dent Mater. 2012; 28(6):642-52.

27. Moszner N, Klapdohr S. Nanotechnology for dental composites. Int J Nanotechnology. 2004;1(1-2):130-56.

28. Mousavinasab SM, Atai M, Alavi B. To compare the microleakage among experimental adhesives containing nanoclay fillers after the storages of 24 hours and 6 months. Open Dent J. 2011; 5:52-7.

29. Beyth N, Domb AJ, Weiss EI. An in vitro quantitative antibacterial analysis of amalgam and composite resins. J Dent. 2007; 35(3):201-6.

30. Busscher HJ, Rinastiti M, Siswomihardjo W, van der Mei HC. Biofilm formation on dental restorative and implant materials. J Dent Res. 2010; 89(7):657-65.

31. Mocanu A, Furtos G, Rapuntean S, Horovitz O, Flore C, Garbo C, et al. Synthesis; characterization and 
antimicrobial effects of composites based on multisubstituted hydroxyapatite and silver nanoparticles. Appl Surf Sci. 2014; 298:225-35.

32. Ai M, Du Z, Zhu S, Geng H, Zhang X, Cai Q et al. Composite resin reinforced with silver nanoparticlesladen hydroxyapatite nanowires for dental application. Dent Mater. 2017; 33(1):12-22.

33. Yoon KY, Hoon Byeon J, Park JH, Hwang J. Susceptibility constants of Escherichia coli and Bacillus subtilis to silver and copper nanoparticles. Sci Total Environ. 2007; 373(2-3):572-5.

34. Ruparelia JP, Chatterjee AK, Duttagupta SP, Mukherji S. Strain specificity in antimicrobial activity of silver and copper nanoparticles. Acta Biomater. 2008; 4(3):707-16

35. Gutiérrez MF, Malaquias P, Matos TP, Szesz A, Souza $\mathrm{S}$, Bermudez $\mathrm{J}$ et al. Mechanical and microbiological properties and drug release modeling of an etch-andrinse adhesive containing copper nanoparticles. Dent Mater. 2017; 33(3):309-20.

36. Sun L, Chow LC. Preparation and properties of nanosized calcium fluoride for dental applications. Dent Mater. 2008; 24(1):111-6.

37. Jeong SH, Hong SJ, Choi CH, Kim BI. Effect of new dentifrice containing nano-sized carbonated apatite on enamel remineralization. Key Eng Mater. 2007; 330-322:291-4.

38. Roveri N, Battistella E, Foltran I, Foresti E, Iafisco M, Lelli M. Synthetic biomimetic carbonate-hydroxyapatite nanocrystals for enamel remineralization. Adv Mat Res. 2008; 47-50:821-4.

39. Jeong SH, Jang SO, Kim KN, Kwon HK, Park YD, Kim BI. Remineralization potential of new toothpaste containing nano-hydroxyapatite. Key Eng Mater. 2006; 309-11:537-40.

40. Lv KL, Zhang JX, Meng XC, Li XY. Remineralization effect of the Nano-HA toothpaste on artificial caries. Key Eng Mater. 2007; 330-2:267-70.

41. Besinis A, van Noort R, Martin N. Infiltration of demineralized dentin with silica and hydroxyapatite nanoparticles. Dent Mater. 2012; 28(9):1012-23.

42. Vollenweider M, Brunner TJ, Knecht S, Grass RN, Zehnder M, Imfeld T et al. Remineralization of human dentin using ultrafine bioactive glass particles. Acta Biomater. 2007; 3(6):936-43.

43. Kishen, A, Shi Z, Shrestha A, Neoh KG. An investigation on the antibacterial and antibiofilm efficacy of cationic nanoparticulates for root canal disinfection. J Endod. 2008; 34(12):1515-20.

44. Saboktakin MR, Tabatabaie RM, Maharramov A, Ramazanov MA. Development and in vitro evaluation of thiolated chitosan--poly(methacrylic acid) nanoparticles as a local mucoadhesive delivery system. Int J Biol Macromol. 2011; 48(3):403-7.

45. Botelho MA, Martins JG, Ruela RS, Queiroz DB, Ruela WS. Nanotechnology in ligature-induced periodontitis: protective effect of a doxycycline gel with nanoparticles. J Appl Oral Sci. 2010; 18(4):335-42.

46. Kasaj A, Röhrig B, Zafiropoulos GG, Willershausen B. Clinical evaluation of nanocrystalline hydroxyapatite paste in the treatment of human periodontal bony defects--a randomized controlled clinical trial: 6-month results. J Periodontol. 2008; 79(3):394-400.

47. Chitsazi MT, Shirmohammadi A, Faramarzie M, Pourabbas R, Rostamzadeh An. A clinical comparison of nano-crystalline hydroxyapatite (Ostim) and autogenous bone graft in the treatment of periodontal intrabony defects. Med Oral Patol Oral Cir Bucal. 2011; 16(3):448-53.

48. Chakraborti M, Jackson JK, Plackett D, Brunette DM, Burt HM. Drug intercalation in layered double hydroxide clay: application in the development of a nanocomposite film for guided tissue regeneration. Int $\mathbf{J}$ Pharm. 2011; 416(1):305-13.

49. Kanaparthy R, Kanaparthy A. The changing face of dentistry: nanotechnology. Int J Nanomedicine. 2011; 6:2799-804.

50. Mitchell JC, Musanje L, Ferracane JL. Biomimetic dentin desensitizer based on nano-structured bioactive glass. Dent Mater. 2011; 27(4):386-93.

51. Lavenus S, Berreur M, Trichet V, Pilet P, Louarn G, Layrolle P. Adhesion and osteogenic differentiation of human mesenchymal stem cells on titanium nanopores. Eur Cell Mater. 2011; 22:84-96.

52. Dong W, Zhang T, Epstein J, Cooney L, Wang H, Li Y et al. Multifunctional nanowire bioscaffolds on titanium. Chem Mater. 2007; 19(18):4454-9.

53. Sadurní N, Solans C, Azemar N, García-Celma MJ. Studies on the formation of $\mathrm{O} / \mathrm{W}$ nano-emulsions, by low-energy emulsification methods, suitable for pharmaceutical applications. Eur J Pharm Sci. 2005; 26(5):438-45.

54. Simonetti MdosPB, de Andrade MP. Anestésicos locais e opióides encapsulados em lipossoma: um avanço farmacotecnico em progresso. Rev Bras Anestesiol. 1996; 46(1):35-42.

55. Ueno T, Tsuchiya H, Mizogami M, Takakura K. Local anesthetic failure associated with inflammation: verification of the acidosis mechanism and the hypothetic participation of inflammatory peroxynitrite. J Inflamm Res. 2008;1:41-8.

56. Franz-Montan M, Silva AL, Cogo K, Bergamaschi Cde C, Volpato MC, Ranali J et al. Liposome-encapsulated ropivacaine for topical anesthesia of human oral mucosa. Anesth Analg. 2007; 104(6):1528-31.

57. Franz-Montan M, Silva AL, Fraceto LF, Volpato MC, Paula Ed, Ranali $\mathrm{J}$ et al. Liposomal encapsulation improves the duration of soft tissue anesthesia but does not induce pulpal anesthesia. J Clin Anesth. 2010; 22(5):313-7.

58. Ribeiro LN, Franz-Montan M, Breitkreitz MC, Alcântara AC, Castro SR, Guilherme VA et al. Nanostructured lipid carriers as robust systems for topical lidocaine-prilocaine release in dentistry. Eur $\mathrm{J}$ Pharm Sci. 2016; 93:192-202.

59. Holpuch AS, Hummel GJ, Tong M, Seghi GA, Pei P, $\mathrm{Ma} \mathrm{P}$ et al. Nanoparticles for local drug delivery to the oral mucosa: proof of principle studies. Pharm Res. 2010; 27(7):1224-36.

60. Silva L, Coutinho A, Fedorov A, Prieto M. Competitive binding of cholesterol and ergosterol to the polyene antibiotic nystatin. A fluorescence study. Biophys J. 2006; 90(10):3625-31.

61. Iamskov IA, Kuskov AN, Babievskiı̌ KK, Berezin BB, Kraiukhina MA, Samoǐlova NA et al. [New liposomal forms of antifungal antibiotics, modified by amphiphilic polymers]. Prikl Biokhim Mikrobiol. 2008; 44(6):688-93.

62. Ng AW, Wasan KM, Lopez-Berestein G. Development of liposomal polyene antibiotics: an historical perspective. J Pharm Pharm Sci. 2003;6(1):67-83. 
63. De Logu A, Fadda AM, Anchisi C, Maccioni AM, Sinico C, Schivo ML et al. Effects of in vitro activity of miconazole and ketoconazole on phospholipid formulations. J Antimicrob Chemother. 1997; 40(6):889-93.

\section{CONFLITO DE INTERESSES}

Os autores declaram não haver conflitos de interesse.

\section{AUTOR PARA CORRESPONDENCIA}

José Alcides Almeida de Arruda alcides_almeida@hotmail.com

Submetido em 25/10/2017 Aceito em 17/11/2017 